\title{
銀デコレーション法を用いた鉄鋼中の水素の可視化
}

\author{
秋山英二1,* 松 岡 三 郎2 \\ 1独立行政法人物質・材料研究機構材料信頼性評価ユニット \\ 2九州大学水素材料先端科学研究センター
}

J. Japan Inst. Met. Mater. Vol. 77, No. 12 (2013), pp. 622-626 Special Issue on Hydrogen and Materials Characteristic in Solids (C) 2013 The Japan Institute of Metals and Materials

\section{Hydrogen Visualization in Steels Using Ag Decoration Method}

Eiji Akiyama1,* and Saburo Matsuoka ${ }^{2}$

${ }^{1}$ Materials Reliability Unit, National Institute for Materials Science, Tsukuba 305-0047

${ }^{2}$ Research Center for Hydrogen Industrial Use and Storage, Kyushu University, Fukuoka 819-0395

The relation between hydrogen distribution and metallographic microstructure was investigated by means of Ag decoration technique for a SUS304 austenitic stainless steel, and martensitic and spheroidized SCM440 steels precharged with hydrogen. Preferential distribution of $\mathrm{Ag}$ particles was seen on the slip lines of the deformed and hydrogen-charged SUS304 stainless steel, suggesting that the slip lines act as hydrogen trap sites. The martensitic SCM440 steel showed almost no selective Ag deposition, indicative of apparently homogeneous distribution of hydrogen. This is probably because the distribution of dislocations with relatively high concentration and the fine structure including lath boundaries etc. acting as hydrogen traps is homogeneous. The spheroidized SCM440 steel showed almost no Ag deposition on the coarse cementite particles and the Ag particle distribution on the other areas did not show clear selectivity. This result suggests that the hydrogen does not diffuse through the cementite particles. The smallest Ag particle size observed by means of atomic force microscope was in the order of $10 \mathrm{~nm}$. Though the minimum size of the $\mathrm{Ag}$ particle does not necessarily indicate the resolution of the hydrogen visualization, $\mathrm{Ag}$ decoration technique is useful to observe the hydrogen distribution. [doi:10.2320/jinstmet.JC201311]

(Received June 18, 2013; Accepted September 11, 2013; Published December 1, 2013)

Keywords: hydrogen, hydrogen embrittlement, delayed fracture, steel, hydrogen visualization, silver decoration

\section{1. 緒言}

高強度鋼, $\mathrm{Al}, \mathrm{Ti}, \mathrm{Zr}$ 合金など種々の金属構造材料は, 大 気腐食, 高温水, サワーガス, 高圧水素ガスなど, その使用 環境に打ける水素の侵入によって水素脆化が引き起こされる 懸念がある. 近年高強度鋼のさらなる高強度化が進められて いることや, 水素エネルギ一利用の推進に伴う高圧水素ガス 容器材料等の安全性の確保が求められることから, 水素脆化 は今また大きな課題となっている.

水素脆化のプロセスや機構を解明する上で, 材料中の水素 の存在 ·分布状態の把握が期待されるが, 最も小さな元素で ある水素は金属材料中を室温でも拡散しガス化して逃散する ため, 水素化物を生成しない場合にはその直接観察は困難で ある.また，例えば高強度鋼の場合には 0.1 mass ppm 以下 の水素量でも水素脆化による破壊が生じ得るが1), 対象とす る水素がこのように微量であることも, その観察を困難にす る要因である.

材料中の水素の分布を観察する手法としては, トリチウム オートラジオグラフィー2-5), 水素マイクロプリント

\footnotetext{
* Corresponding author, E-mail: akiyama.eiji@nims.go.jp
}

法 $^{6-12)}$, 銀デコレーション法13-15), SIMS (Secondary Ion Mass Spectrometry, 二次イオン質量分析)16)などが挙げら れる. 銀デコレーション法は, 水素マイクロプリント法と同 様に比較的簡便に水素分布を可視化できる手法である.

銀デコレーション法は, $\mathrm{Ag}$ の錯イオンと平衡する $\mathrm{Ag}$ イ オン $($ 式 $(1))$ が金属表面の吸着水素 $\left(\mathrm{H}_{\mathrm{ads}}\right)$ によって還元され 析出する(式 (2))ことを利用して, 析出した $\mathrm{Ag}$ 粒子の観察 から水素分布を可視化する手法である.

$$
\begin{aligned}
& \mathrm{Ag}(\mathrm{CN})_{2}{ }^{-} \longrightarrow \mathrm{Ag}^{+}+2 \mathrm{CN}^{-} \\
& \mathrm{H}_{\mathrm{ads}}+\mathrm{Ag}^{+} \longrightarrow \mathrm{H}^{+}+\mathrm{Ag}
\end{aligned}
$$

著者らはこの銀デコレーション法を用いて, すきま腐食内 部の水素侵入分布のマッピング17-19) や, 単結晶ステンレス 鋼の水素脆化によるき裂発生部や破断部の水素分布観察を行 っている ${ }^{20)}$.これらは比較的マクロな水素分布の観察であ るが，よりミクロな金属組織と水素存在位置の対応を銀デコ レーション法で可視化することができれば，水素脆化に及ぼ す水素の役割を検討する上で有用な知見が得られると期待さ れる. そこで, 本研究では銀デコレーション法による金属組 織と水素分布の関係の観察を，水素をチャージした SUS304 鋼，SCM440 マルテンサイト鋼および球状化鋼を例として 試みた。 


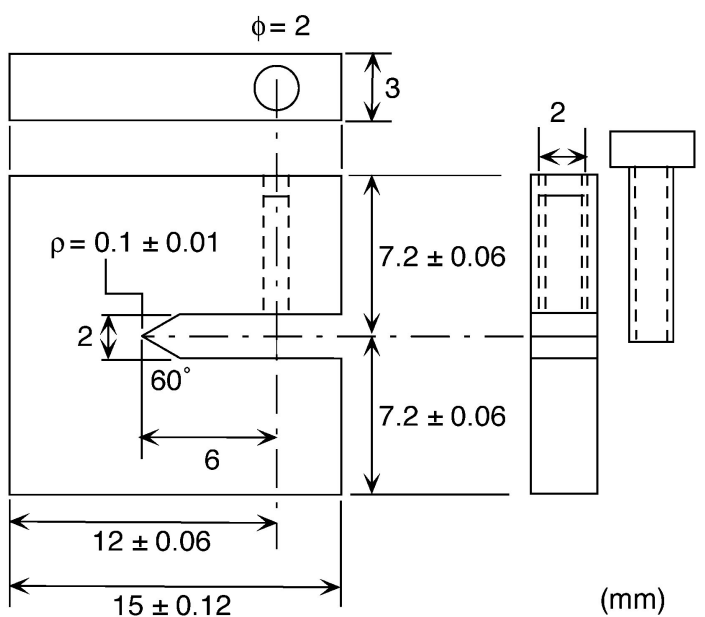

Fig. 1 Dimensions (in $\mathrm{mm}$ ) of a compact tension specimen.

Table 1 Chemical composition of SUS304 and SCM440 steels. (mass\%)

\begin{tabular}{cccccccccc}
\hline & $\mathrm{C}$ & $\mathrm{Si}$ & $\mathrm{Mn}$ & $\mathrm{P}$ & $\mathrm{S}$ & $\mathrm{Cr}$ & $\mathrm{Ni}$ & $\mathrm{Mo}$ & $\mathrm{Fe}$ \\
\hline SUS304 & 0.06 & 0.60 & 1.57 & 0.032 & 0.009 & 18.30 & 8.30 & - & bal. \\
\hline SCM440 & 0.40 & 0.24 & 0.81 & 0.020 & 0.007 & 1.03 & - & 0.16 & bal. \\
\hline
\end{tabular}

\section{2. 実 験 方 法}

用いた材料は, SUS304 鋼および SCM440 鋼である. SUS304 鋼の場合，溶体化した材料を用いて Fig. 1 に示す ボルトロード式の CT 試験片を作製した。用いた SUS304 鋼の組成は Table 1 に示す. 観察用の試験片の片面は電解研 磨した，試験片の背面にひずみゲージを貼り，背面ひずみを $600 \mu \varepsilon$ になるようにボルトを締付けて応力を負荷し，その状 態で水素チャージを行った。水素チャージ条件は，室温， $0.1 \mathrm{M} \mathrm{NaOH}$ 水溶液中で試験片をカソードとした $1 \mathrm{~mA} / \mathrm{cm}^{2}$ での定電流分極を $2 \mathrm{~h}$ である. 対極には Ptワイヤを用い た. 水素チャージ後, 試験片は蒸留水, アセトンで洗浄, 乾 燥した後に，ボルトを緩めて除荷し， $4.3 \mathrm{mM} \mathrm{K}\left[\mathrm{Ag}(\mathrm{CN})_{2}\right]$ 水溶液中に室温で $10 \mathrm{~min}$ 浸漬し銀デコレーションを行っ た. 銀デコレーション法による $\mathrm{Ag}$ 粒子の析出の効率は $\mathrm{pH}$ に影響を受けることが Saitohらにより報告されている が15)，本研究では $\mathrm{pH}$ 調整は行わず，作製ままの溶液を用い た。

銀デコレーション後の試験片表面の観察は, 光学顕微鏡, SEM 抢びAFM (Atomic Force Microscope：原子間力顕 微鏡)で行い，表面に分散した粒子が $\mathrm{Ag}$ であることは EPMAにより確認した.

$\mathrm{SCM} 440$ 鋼は, $880^{\circ} \mathrm{C}, 45 \mathrm{~min}$ 焼入れ, $450^{\circ} \mathrm{C}, 90 \mathrm{~min} の$ 焼戻しによりマルテンサイト組織とした試料と, $700^{\circ} \mathrm{C}$ で 97\%加工し，同温度で $168 \mathrm{~h}$ 加熱し炭化物を球状化した試料 の 2 種を作製した。それぞれ，厚さ $0.5 \mathrm{~mm}$ ，縦横約 $15 \mathrm{~mm}$ の板状試験片に加工し, 観察用の片面を電解研磨した. SCM440 鋼の組成は Table 1 に示す.

両鋼種の板状試験片の場合，水素チャージには Fig. 2 に

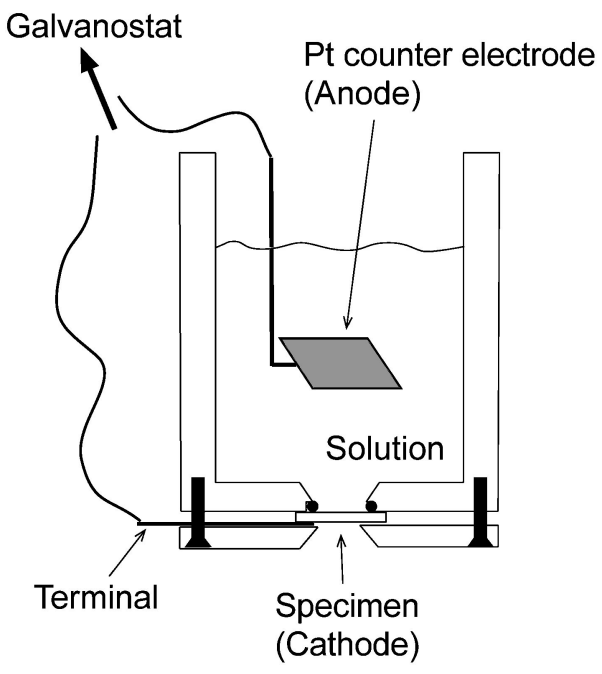

Fig. 2 Schematic drawing of electrochemical setup for hydrogen charging.

示す電気化学セルを用いた。 セルの底面には円形の穴があ り，ここに内径 $8 \mathrm{~mm}$ の o-ring を用いて試験片を固定し た。試験片には $\mathrm{Al}$ 箔を接触させ固定して導通を取った。水 素チャージには $0.5 \mathrm{M} \mathrm{NaCl}+0.04 \mathrm{M} \mathrm{NH}_{4} \mathrm{SCN}$ 水溶液を用 い，室温で $1 \mathrm{~mA} / \mathrm{cm}^{2}$ の電流密度で定電流水素チャージを 行った. 試験片の水素チャージ溶液に接する面は, 電解研磨 面の反対面とした。水素チャージは $3 \mathrm{~h}$ 行い, その後 SUS304 試験片に用いたのと同じく $4.3 \mathrm{mM} \mathrm{K}\left[\mathrm{Ag}(\mathrm{CN})_{2}\right]$ 水 溶液を用い，室温で $30 \mathrm{mim}$ 浸漬し銀デコレーションを行っ た。な拈，この場合観察面の反対面からチャージを行ったの は, SUS304 鋼と比較して耐食性の低いこれらの鋼種の観察 面の腐食や污染をできるだけ防ぐことと，水素侵入効率では なく拡散により生じた水素の分布状態を観察することを目的 としている.オーステナイトの SUS304 鋼の場合は水素の 拡散が遅いため, 観察面からの水素チャージを行っているが, $\mathrm{SCM} 440$ の両鋼種の場合は，SUS304 鋼と比較して水素の 拡散が速いために片面からの水素チャージでも反対面に水素 が到達する．このことは，試験片の厚さと同様の鋼種の電気 化学水素的透過試験結果加推定される ${ }^{21)}$.

\section{3. 実 験 結 果}

Fig. 3 にひずみを加えた SUS304 鋼試験片の切欠部周辺 の表面の銀デコレーション像を示す．図の上部に見られるの は CT 試験片の切欠底である．表面に析出した $\mathrm{Ag}$ 粒子は図 中の白い点として観察される. Fig. 4 にはこの粒子が $\mathrm{Ag}$ で あることをEPMA により確認した結果を示す。図中左上か ら右下にかけて斜めに走っている線は, 電解研磨により掘れ た粒界であると考えられる．また，Fig. 4(a)に見られる黒 い3つの点は電解研磨時に生じたピットと思われる。

Fig. 4(b)に見られるAgの分布と, Fig. 4(a)の SEM 像 で見られる白点の分布とはよく対応していることから，Fig. 4(a)で観察されている粒子が $\mathrm{Ag}$ からなることが確認でき る. 副生成物である $\mathrm{AgCN}$ (水素での $\mathrm{Ag}$ イオンの還元によ 
る生成物ではない)は針状結晶の形態を示すが13)，観察され た粒子は半球もしくは球状であることから，これらの粒子は 吸着水素により $\mathrm{Ag}$ イオンが還元されて生成した金属状態の Agであると考えられる。

試験片表面では，すべりに対応すると考えられる $\mathrm{Ag}$ 粒子

(a)

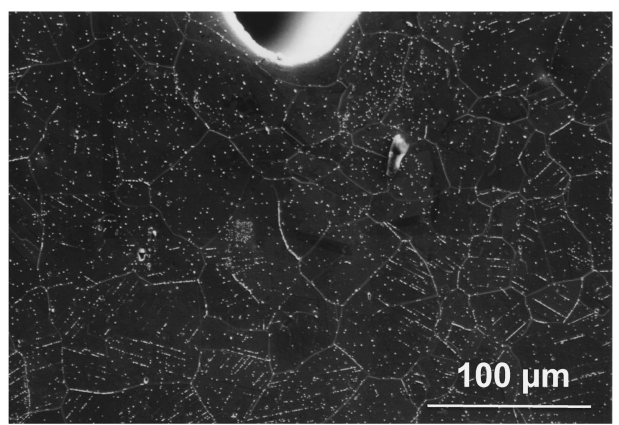

(b)

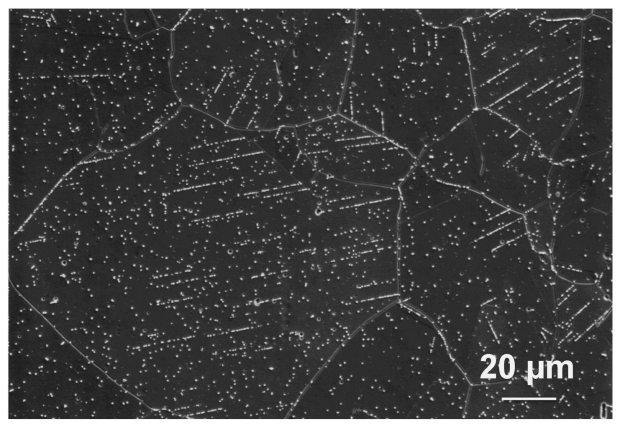

Fig. 3 SEM photographs of the Ag decorated surface of the deformed SUS304 CT specimen. (a) Lower magnification, (b) Higher magnification.

(a)

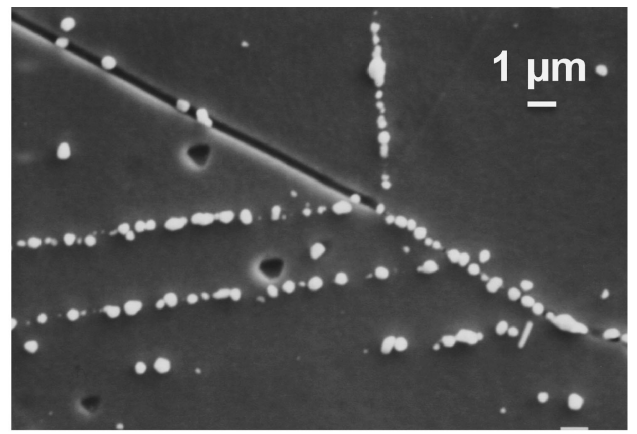

(b)

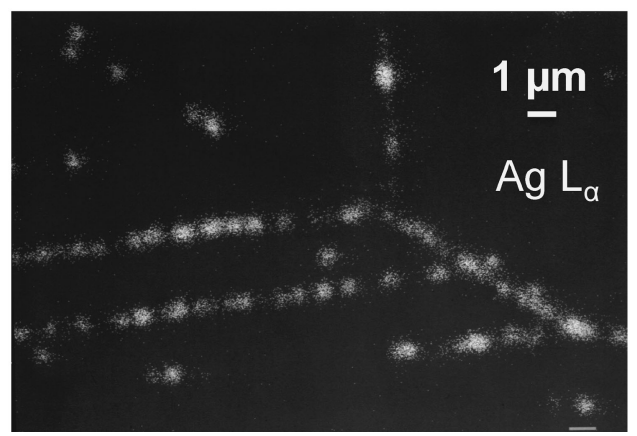

Fig. 4 SEM photograph and $\mathrm{Ag} \mathrm{L}_{\alpha}$ mapping image of the $\mathrm{Ag}$ decorated surface of the deformed CT specimen of SUS304 steel. (a) SEM photo, (b) Ag $\mathrm{L}_{\alpha}$ mapping.
の選択的な分布が見られた。このことから，水素による $\mathrm{Ag}$ イオン還元反応がすべり上で抗こていることが分かる.

一方，全体的には粒界上の $\mathrm{Ag}$ 粒子の選択的な分布は見ら れなかったが，一部の粒界上には選択的な析出が見られた. その場合でも，粒界上に一様に $\mathrm{Ag}$ 粒子が見られる訳ではな く，1つの粒界の線上の一部で $\mathrm{Ag}$ 粒子の密度が高い. 例え ば Fig. 4(a)のように，Ag 粒子の析出が見られたすべり線と 粒界とが交わった付近で, 粒界上の $\mathrm{Ag}$ 粒子の選択的析出が 見られている.

この銀デコレーションを行った SUS304 鋼試料表面を AFM 観察した結果を Fig. 5 に示す. AFM により段差が確 認できるところが大角境界である焼鈍双晶界面であると判断 し図中に TWで示した。 また，溝状になっている部分は， 電解研磨時に掘れた粒界 $(\mathrm{GB})$ で, 直線状に選択的に $\mathrm{Ag}$ 粒 子が析出している部分はすべり線 $(\mathrm{SL})$ と考えられる。すべ り線上の選択的な銀粒子の析出から，水素の選択的な分布が 示唆される. 焼鈍双晶界面では選択的な $\mathrm{Ag}$ 粒子析出は見ら れなかった。

Fig. 5(b)に見られるように，観察される析出 $\mathrm{Ag}$ 粒子は 小さいものでは数十 $\mathrm{nm}$ オーダーであった. 後に考察に記す ように，微小な粒子径なりに水素可視化の解像度があるとは 言えないものの, 銀デコレーション法は微細な組織構造と水 素分布の関係を見るために有効な手法であると期待される.

Fig. 6 は水素をチャージした SCM440 マルテンサイト鋼 で銀デコレーションを行い，AFM を用いて観察した例であ る. 析出した $\mathrm{Ag}$ 粒子が微細なセメンタイト粒子と同程度の 大きさ以下の場合には見分けがつきづらいが，より大きな粒 子，もしくは明らかに高さのある粒子(図中，より白く表現
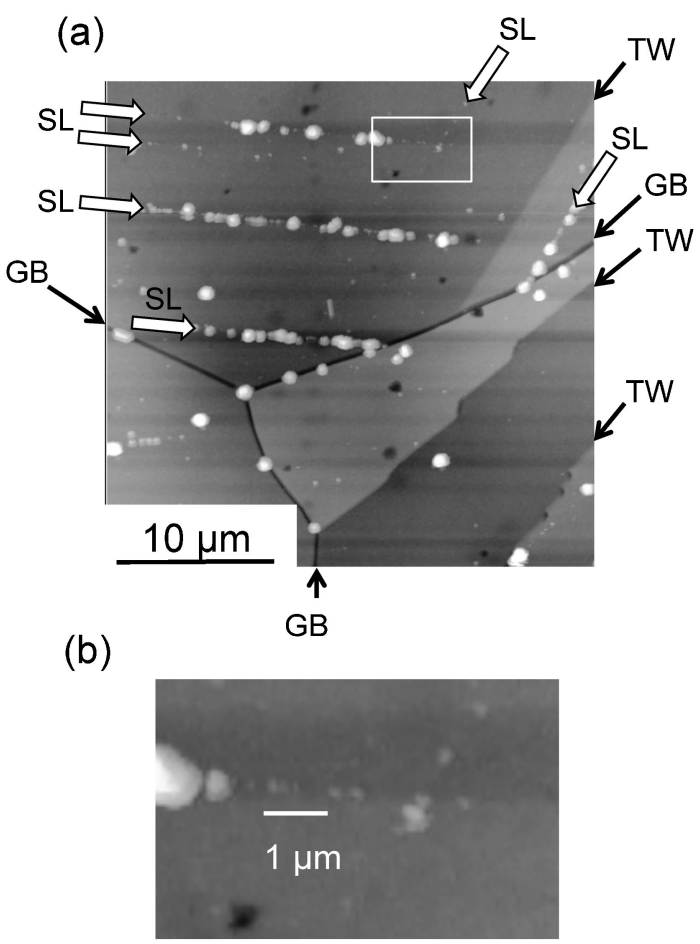

Fig. 5 (a) AFM image of the Ag decorated surface of the deformed CT specimen of SUS304 steel. GB shows grain boundary, TW twin and SL slip line. (b) A magnified image of the area shown by the white square in (a). 
(a)

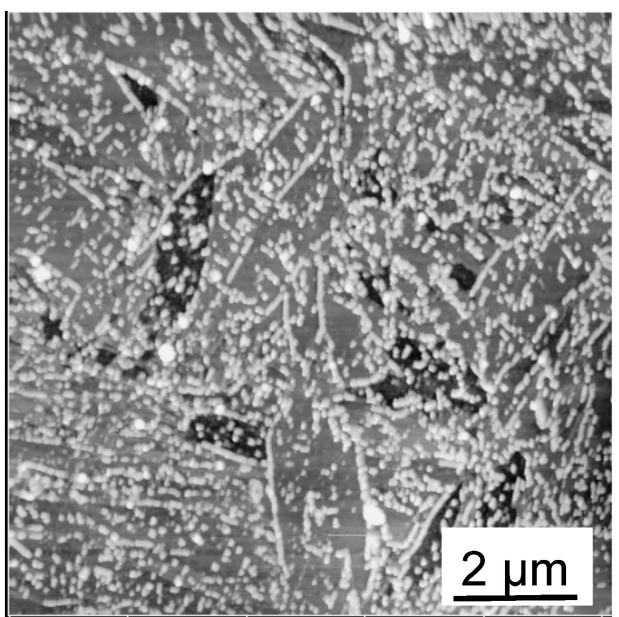

(b)

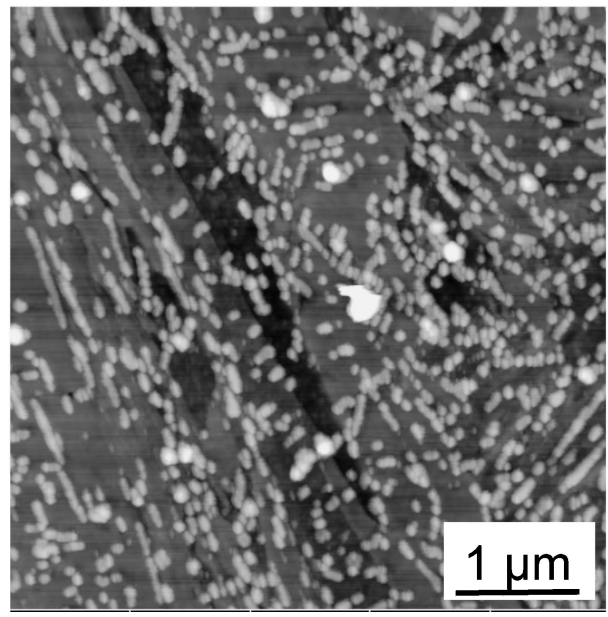

Fig. 6 AFM image of the $\mathrm{Ag}$ decorated surface of the SCM440 martensitic steel specimen.

されている粒子)は $\mathrm{Ag}$ であると考えられる. Fig. 6 に示す 例以外にも何力所かでの観察を試みたが，旧 $\gamma$ 粒界抢よびそ の下部組織のパケット，ブロック，ラスの境界と考えられる 場所での選択的な $\mathrm{Ag}$ の析出は見られず，Ag 粒子はほぼラ ンダムな分散を呈した．前述の SUS304 の場合には欠陥上 の水素の選択的存在が示唆されたが，マルテンサイト鋼の場 合, 水素の分布は見かけ上概祖均一であった. セメンタイト とマトリックスの界面や転位が水素トラップとして働くこと が昇温脱離の結果から報告されている22)一方， $\varepsilon$ 炭化物やセ メンタイトは水素のトラップとならないことなどが議論され ている23)。本実験ではセメンタイトとの有意な関係を示す ような選択的な $\mathrm{Ag}$ の析出は見られなかった。仮に水素濃度 がセメンタイトとマトリックス界面で高い場合でも，微細な 組織にトラップされた水素が可視化に十分な $\mathrm{Ag}$ 粒子の析出 には量的に満たない，もしくはトラップされた水素が試料表 面で $\mathrm{Ag}$ イオンを還元するに十分移動しないことなどによっ て, 可視化結果に現れない可能性も考えられるため, セメン タイト/フェライト界面の水素の濃化を否定することはでき ないものの,この観察結果からは特に微細組織との関連が見 られなかった。

$\mathrm{SCM} 440$ 球状化鋼試料の銀デコレーション例を Fig. 7 に 示す. 蜂の巣状の模様が見られるのは, 球状化したセメンタ

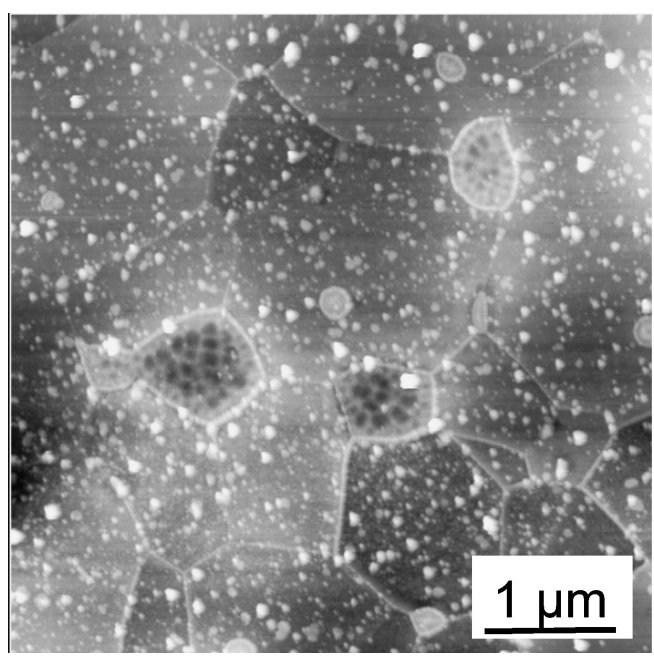

Fig. 7 AFM image of the Ag decorated surface of the SCM440 spheroidized steel specimen.

イトである. 球状化したセメンタイト上には $\mathrm{Ag}$ 粒子はほと んぞ見られなかった．セメンタイト上を除くと，ほほ $\mathrm{Ag}$ 粒 子の析出は均一であり, 粒界上の選択的な $\mathrm{Ag}$ 粒子の析出も 見られなかった。

な抢，先に示した SCM440 マルテンサイト鋼 (Fig. 6) と, この SCM440 球状化鋼での水素チャージおよび銀デコ レーションの方法は同様であるが，球状化 SCM440 鋼の方 が表面の析出 $\mathrm{Ag}$ 粒子が多く見られている。これは，水素の 拡散がマルテンサイト鋼中よりも球状化鋼中で速く, 同じ水 素チャージ時間で水素チャージ面から観察面に到達した水素 が球状化鋼の方が多かったこと, また，銀デコレーション中 に拡散する水素もまた球状化鋼の方が多かったことが原因と 考えられる.

この球状化鋼の銀デコレーション法による観察結果から は, セメンタイト中が水素の拡散パスになっていないこと, また，フェライト粒界が優先的な拡散パスになっていないこ とがうかがわれる。

\section{4. 考 察}

銀デコレーション法を用いて，SUS304 オーステナイトス テンレス鋼，SCM440 マルテンサイト鋼抢よびSCM440 球 状化鋼を例として水素分布観察を試みた。AFMによる観察 では, 数 $10 \mathrm{~nm}$ オーダーの $\mathrm{Ag}$ 粒子の分布も観察された。 水素マイクロプリント法の場合には, 直径 $300 \mathrm{~nm}$ 程度の $\mathrm{AgBr}$ 粒子を含む乳剂を塗布して, 水素によって還元された $\mathrm{Ag}$ を観察するが ${ }^{10)}$ ，これと比較して高い分解能を有するこ とが期待できる、しかしながら，銀デコレーション法で観察 される $\mathrm{Ag}$ 粒子は微細なものが高密度で分散すると限らず, $\mathrm{Ag}$ 粒子の析出が増加する場合には, 径の大きい粒子に成長 する傾向が見られる。これは, $\mathrm{Ag}$ 粒子近傍の吸着水素が表 面拡散で $\mathrm{Ag}$ 粒子上に移動し $\mathrm{Ag}$ 還元が起きたことを示唆し ている.このことから，観察される微小な $\mathrm{Ag}$ 粒子の大きさ なりの解像度を示すわけではないことを考慮する必要がある が，SUS304 試料の観察例のように，比較的良好な水素分布 
可視化が可能であった.

銀デコレーション法や水素マイクロプリント法では, 表面 の吸着水素が Ag イオンを還元することを利用しているが， 吸着水素の位置選択性だけではなく, 水素拡散の選択性を反 映する．ある特定のサイトに水素が選択的にトラップされて いる場合，そのサイトの表面の吸着水素が多いか，そのサイ 卜を通した表面への水素の拡散が速い場合に，表面に析出す る $\mathrm{Ag}$ 粒子が多くなると考えられる. 逆に，水素トラップサ イトでの水素の拡散が遅い場合には，そのサイトでの水素濃 度が高くても表面での $\mathrm{Ag}$ 析出量に反映されないと考えられ る.

微細なセメンタイトとフェライトマトリックスの界面が水 素のトラップサイトとなるかどうかについては議論があ る22,23). これと粗大に球状化したセメンタイトとフェライト マトリックスの界面とは必ずしも同じではないものの，銀デ コレーション法により選択的な $\mathrm{Ag}$ 粒子の析出が見られるか ぞうかについては興味が持たれる。しかし，その界面でのト ラップ水素の濃化に対応した $\mathrm{Ag}$ 粒子分布は見られなかっ た. 前述のように，この界面を通した水素の拡散が遅い場合 でも $\mathrm{Ag}$ 粒子の選択的な析出が見られない可能性もあるた め, 必ずしも水素濃度の濃化がなかったとも断定できない. この試験の場合, 確からしいのは, セメンタイト粒子中は水 素の拡散パスとなっていないということである. 銀デコレー ション法は, 表面に拡散し吸着水素となった水素が $\mathrm{Ag}$ イオ ンを還元することによって可視化を行うものであり，水素存 在位置だけでなく，拡散の特性の影響を受けると考えられる.

ひずみを与えた SUS304 オーステナイトステンレス鋼を 例に銀デコレーション法を用いた観察を行った結果, すべり 線での選択的な水素分布を示唆する結果が得られた。 $\mathrm{SCM} 440$ 鋼と異なり，水素拡散が遅いオーステナイト鋼で あるため，水素チャージ面と銀デコレーションを施した面は 同じである.このため，特異的に見られたすべり線上の水素 が，拡散集積したものなのか，あるいは水素チャージ時に水 素が優先的に侵入するサイトであった可能性など，今後より 詳細な検討が必要であると思われるが，すべりと水素存在位 置の相関があることは明らかと言える，表面に析出した Ag 粒子の体積を考慮すると, 表面に吸着していた水素だけでは なく, 銀デコレーション溶液に浸漬している間に内部から拡 散した水素による $\mathrm{Ag}$ イオンの還元も含まれていると考えら れる.

以上のように, 銀デコレーション法により析出した Ag 粒 子分布は, 表面の吸着水素濃度の情報だけでなく, 鋼中の水 素の拡散も反映すると考えられる. したがって, 鋼中の水素 の存在状態をより詳細に解析するにあたっては，水素拡散を 反映する銀デコレーション法あるいは水素マイクロプリント 法と, 静止した水素(トリチウム)を観察するオートラジオグ ラフィーとの併用が望ましい12).

\section{5. 結論}

SUS304 オーステナイトステンレス鋼と SCM440 マルテ
ンサイト抢よび球状化鋼を例にとり，銀デコレーション法を 用いた水素可視化を行った。ひずみを与えた SUS304 鋼で は，すべり線上の選択的な $\mathrm{Ag}$ 粒子の析出が見られ，水素の 選択的な存在が示唆された. SCM440マルテンサイト鋼の 場合には，Ag 粒子分布はほぼランダムであったＳCM440 球状化鋼の場合には，セメンタイト上の $\mathrm{Ag}$ 粒子析出はほと んど見られず，その他の場所ではほぼ均一に分散した。この ことから, セメンタイト粒子は水素の拡散パスとなっていな いことが推測された．銀デコレーション法では，表面への水 素の拡散の影響が大きいことを考慮した結果の解析が必要で あると考えられるが，数十 $\mathrm{nm}$ スケール析出した粒子の選択 的な分布が観察されたことから，比較的簡便に解像度の高い 可視化が期待できる手法と考えられる.

SEM および EPMA 測定でご協力頂いた東北大学金属材 料研究所浅見勝彦教授および村上義弘氏に感謝いたします。 また, 有意義なご助言を頂いた独物質・材料研究機構早川正 夫博士に感謝いたします。

\section{文献}

1) N. Suzuki, N. Ishii, T. Miyagawa and H. Harada: Tetsu-toHagané 79 (1993) 227-232.

2) H. Saito, K. Miyazawa and M. Mori: J. Japan Inst. Metals 62 (1998) 215-223

3) L. M. Foster, T. H. Jack and W. W. Hill: Metall. Trans. 1(1970) 3117-3124.

4) H. Saitoh and M. Mori: Kinzoku, Materials Science \& Technology 57 (1997) 1027-1036.

5) H. Saitoh, T. Hishi, T. Misawa, T. Ohnishi, Y. Noya, T. Matsuzaki and T. Watanabe: J. Nucl. Mater. 258-263(1998) $1404-1408$

6) S. Kuramoto, K. Ichitani, A. Nagao and M. Kanno: Tetsu-toHagané 86 (2000) 17-23.

7) K. Koyama, G. Itoh and M. Kanno: J. Japan Inst. Metals 62 (1998) 790-795.

8) M. I. Luppo and J. Ovejero-García: Corros. Sci. 32 (1991) 11251136.

9) A. Nagao, S. Kuramoto, M. Kanno and T. Shiraga: Tetsu-toHagané 86 (2000) 4-31.

10) J. Ovejero-García: J. Mater. Sci. 20(1985) 2623-2629.

11) T. E. Peréz, J. Ovejero-García, D. Inend and P. Agua Pesada: Scr. Metall. 16(1982) 161-164.

12) H. K. Yalçí and D. V. Edmonds: Mater. Charact. 34(1995) 97104.

13) J. Yao and J. R. Cahoon: Metall. Trans. A 21 (1990) 603-608.

14) T. Schober and C. Dieker: Metall. Trans. A 14 (1983) 24402442.

15) H. Saitoh, T. Hishi and T. Misawa: Mater. Trans., JIM 37 (1996) 373-378

16) K. Takai, Y. Homma, K. Izutsu and M. Nagumo: J. Japan Inst. Metals 60 (1996) 1155-1162.

17) T. Sundararajan, E. Akiyama, Y. Katada and K. Tsuzaki: ISIJ Int. 46(2006) 1081-1085.

18) T. Sundararajan, E. Akiyama and K. Tsuzaki: Electrochem. Solid St. 8(2005) B30-B33.

19) T. Sundararajan, E. Akiyama and K. Tsuzaki: Scr. Mater. 53 (2005) 1219-1223.

20) M. Koyama, E. Akiyama, T. Sawaguchi, K. Ogawa, I. V. Kireeva, Y. I. Chumlyakov and K. Tsuzaki: Corros. Sci. 75 (2013) 345-353

21) E. Akiyama, S. Li, T. Shinohara, Z. Zhang and K. Tsuzaki: Electrochim. Acta 56(2011) 1799-1805.

22) W. Y. Choo and J. Y. Lee: J. Mater. Sci. 17(1982) 1930-1938.

23) F. G. Wei and K. Tsuzaki: Scr. Mater. 52(2005) 467-472. 